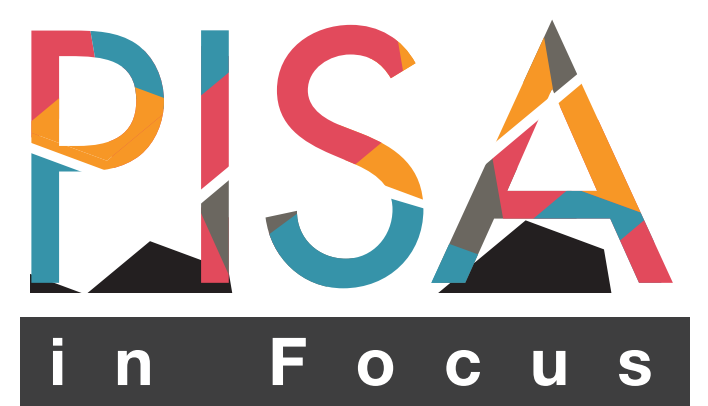

The socio-economic gap in foreign-language learning

Programme for International Student Assessment 


\section{1he socio-economic gap in foreign-language learning}

- On average across OECD countries in 2018, 15-year-old students spent about 3.6 hours per week in regular foreign-language lessons. This is about the same amount of time students spent in regular lessons on core subjects such as language-of-instruction, mathematics and science.

- On average across OECD countries, students in socio-economically advantaged schools spend almost one hour more per week in foreign-language lessons than students in disadvantaged schools.

- Education systems that have a smaller socio-economic gap in foreign-language learning time also exhibit greater equity in student performance in reading, mathematics and science, even after accounting for per capita GDP.

Teaching foreign languages has become a major goal for many education systems around the world. In today's increasingly interconnected world, speaking multiple languages improves employability, fosters respect for people from other cultures, and gives young people direct access to content that would otherwise be inaccessible, including literature, music, theatre and cinema (OECD, 2020a).

For the first time in 2018, PISA asked students whether they studied foreign languages at school and how much class time they had on foreign languages per week ${ }^{1,2}$. Results show that learning foreign languages is widely available to 15-year-olds in today's education systems. However, these opportunities are not evenly distributed among students of different socio-economic status: students in advantaged schools have more opportunities to learn foreign languages than students in disadvantaged schools. These socio-economic disparities in foreign-language instruction time are telling as they correlate to inequity in student achievement in other areas - in reading, for example. These results suggest the existence of a social divide not previously measured that leaves some students unprepared for effective communication with others from different cultural and language backgrounds.

\section{Opportunities for learning foreign languages are widely available}

The number of students who do not receive foreign-language lessons at school is rather small in most PISA-participating countries and economies. On average across OECD countries in 2018, only
$12 \%$ of students reported that they do not learn any foreign languages at school while $88 \%$ reported that they learn one or more. In 48 out of 65 countries and economies with data on this question, the proportion of students who reported not learning any foreign languages at school was only $10 \%$ or less. Exceptions to this pattern are Australia, New Zealand and Scotland (United Kingdom) where more than $60 \%$ of students reported not learning any foreign languages at school. In Canada, Brunei Darussalam, Malaysia and Saudi Arabia, about a third of students do not learn foreign languages at school.

Furthermore, the amount of time that students spend learning foreign languages in regular school lessons is, on average, as much as they spend on core subjects such as language-of-instruction, mathematics and reading. On average across OECD countries in 2018, students spent about 3.6 hours per week in foreign-language lessons; 3.7 hours per week in language-of-instruction and mathematics lessons; and 3.4 hours per week in science lessons.

In 28 countries and economies, students spent more time in foreign-language lessons than in language-of-instruction lessons; the opposite was observed in 45 countries and economies.

Learning time in foreign-language lessons varies across countries. The least amount of learning time in foreign-language classes on average was observed in Australia and New Zealand (1.2 hours). By contrast, average learning time per week in foreign-language lessons was the longest in Luxembourg (6.2 hours) and Costa Rica (5.4 hours). 
Learning time in foreign language and language-of-instruction lessons, by schools' socio-economic profile [1/2]

Based on students' reports

$\square \square$ Foreign language lessons

$\diamond$ Language-of-instruction lessons

Positive difference

Learning time per week in regular school lessons (hours)

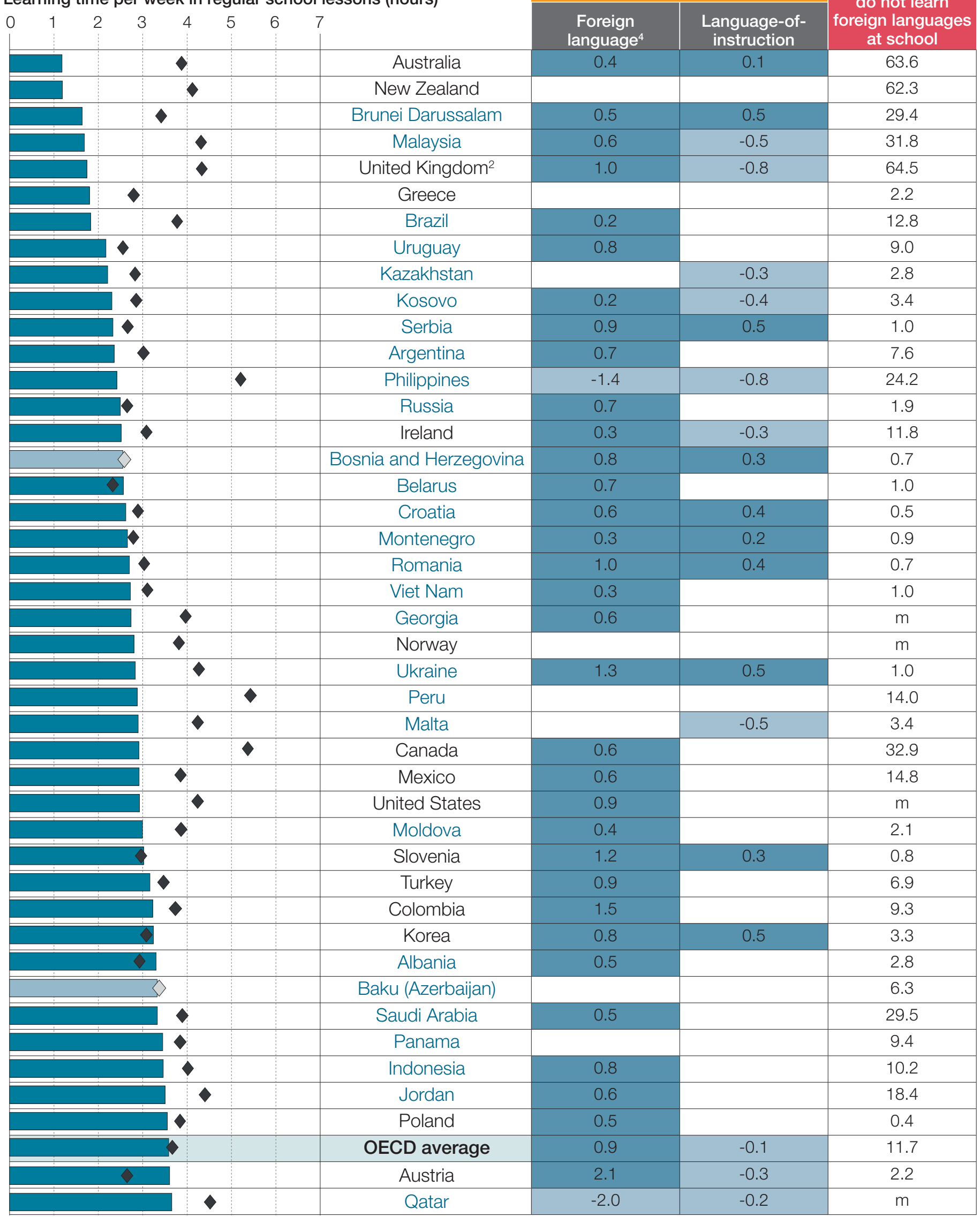

C) OECD 2021 | PISA in Focus 2021/116 (November) 3 


\section{Learning time in foreign language and language-of-instruction lessons, by schools" socio-economic profile [2/2]}

\section{Based on students' reports}

$\square$ Foreign language lessons

$\checkmark>$ Language-of-instruction lessons

Learning time per week in regular school lessons (hours)
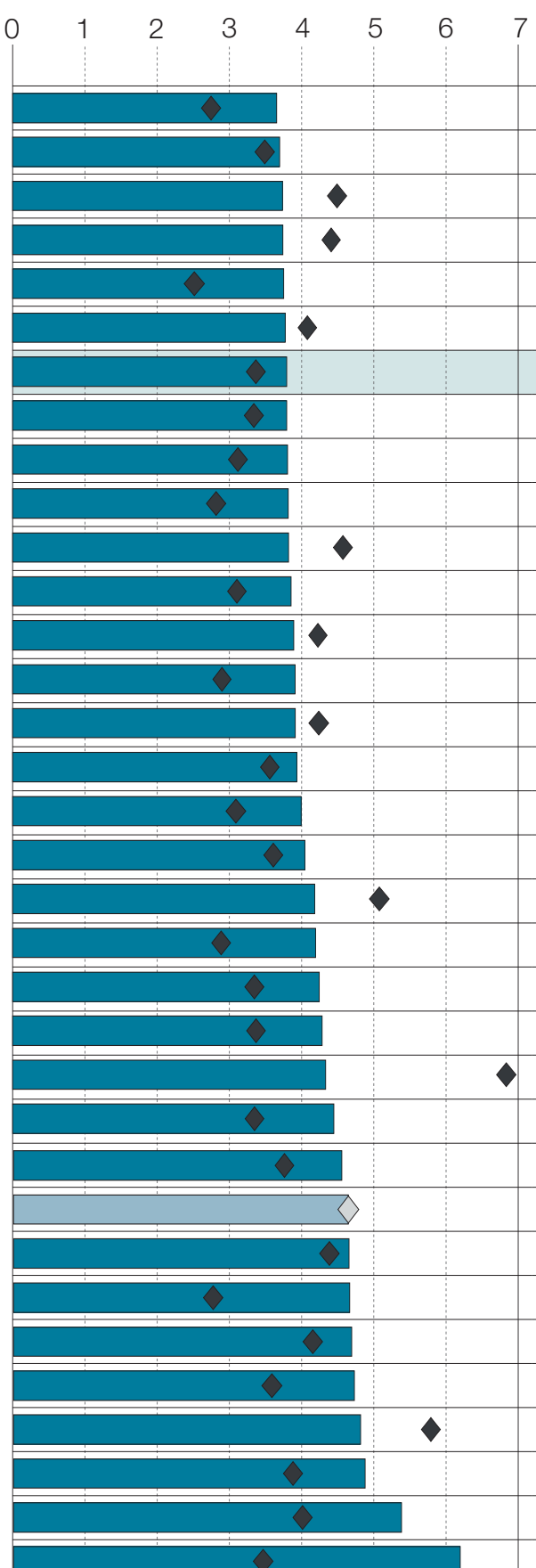

Positive difference

\begin{tabular}{|c|}
\hline Latvia \\
\hline Lithuania \\
\hline United Arab Emirates \\
\hline Dominican Republic \\
\hline Finland \\
\hline Portugal \\
\hline EU $_{\text {average }}^{3}$ \\
\hline Israel \\
\hline Sweden \\
\hline Netherlands \\
\hline Italy \\
\hline Czech Republic \\
\hline Chinese Taipei \\
\hline Thailand \\
\hline Macao (China) \\
\hline Spain \\
\hline Estonia \\
\hline Japan \\
\hline Hong Kong (China) \\
\hline Bulgaria \\
\hline Switzerland \\
\hline Slovak Republic \\
\hline Chile \\
\hline Germany \\
\hline France \\
\hline B-S-J-Z (China) \\
\hline Singapore \\
\hline Hungary \\
\hline Iceland \\
\hline Belgium \\
\hline Denmark \\
\hline Morocco \\
\hline Costa Rica \\
\hline Luxembourg \\
\hline
\end{tabular}

Negative difference

$\square$ Difference is not significant

\begin{tabular}{|c|c|c|}
\hline \multicolumn{2}{|c|}{$\begin{array}{l}\text { Difference between students in } \\
\text { advantaged and disadvantaged } \\
\text { schools }{ }^{1} \text { (in hours): }\end{array}$} & \multirow{2}{*}{$\begin{array}{c}\text { Proportion of } \\
\text { students who } \\
\text { do not learn } \\
\text { foreign languages } \\
\text { at school }\end{array}$} \\
\hline $\begin{array}{c}\text { Foreign } \\
\text { language }^{4}\end{array}$ & $\begin{array}{l}\text { Language-of- } \\
\text { instruction }\end{array}$ & \\
\hline 0.3 & & 0.5 \\
\hline 0.3 & 0.2 & 0.2 \\
\hline-3.1 & -0.4 & 16.2 \\
\hline-1.4 & -2.4 & 6.3 \\
\hline 0.4 & & $\mathrm{~m}$ \\
\hline-0.3 & -0.3 & 1.7 \\
\hline 1.0 & -0.2 & 1.8 \\
\hline \multirow[t]{2}{*}{-0.6} & -0.3 & 6.3 \\
\hline & -0.3 & $\mathrm{~m}$ \\
\hline 2.1 & -0.7 & $\mathrm{~m}$ \\
\hline 0.5 & -0.5 & 0.5 \\
\hline 1.0 & -0.5 & $\mathrm{~m}$ \\
\hline 1.2 & 1.2 & 8.0 \\
\hline 1.4 & -0.6 & 7.7 \\
\hline-0.6 & 0.5 & 9.7 \\
\hline 0.4 & -0.2 & 2.6 \\
\hline 0.7 & & 0.6 \\
\hline \multirow[t]{2}{*}{1.7} & 1.0 & $\mathrm{~m}$ \\
\hline & & 21.3 \\
\hline 1.4 & -0.6 & 0.4 \\
\hline 1.5 & -0.6 & 6.4 \\
\hline 1.9 & -0.8 & 1.0 \\
\hline 0.6 & & 12.7 \\
\hline 2.4 & -0.8 & 1.7 \\
\hline \multirow[t]{2}{*}{1.5} & & 2.2 \\
\hline & & $\mathrm{m}$ \\
\hline-0.7 & -0.7 & 5.7 \\
\hline 3.8 & & 0.6 \\
\hline 0.4 & & 2.7 \\
\hline 2.6 & & $\mathrm{~m}$ \\
\hline 0.6 & & $\mathrm{~m}$ \\
\hline 2.9 & -1.0 & 5.0 \\
\hline 2.1 & & 5.3 \\
\hline 1.7 & -0.2 & $\mathrm{~m}$ \\
\hline
\end{tabular}

Countries and economies are ranked in ascending order of the learning time per week in foreign language lessons.

Note: The diamonds indicating the learning time per week in language of instruction are marked in a darker tone if the difference in average learning time per week between foreign language and language-of-instruction lessons is statistically significant.

1. Socio-economically advantaged/disadvantaged schools are schools in the top/bottom $25 \%$ of the national distribution of the school-level ESCS index. The school-level ESCS index is the average ESCS index among students in a school. The ESCS index is the PISA index of students' economic, social and cultural status.

2. Proportion of students who do not learn foreign languages at school corresponds to Scotland (United Kingdom).

3. The EU average is the unweighted mean of the data values of countries that are members of the European Union for which data are available or can be estimated. Cyprus is not included.

4. The difference in learning time in foreign-language between students in advantaged and disadvantaged schools is statistically significant even after accounting for student socio-economic status in most participating countries and economies.

Source: OECD, PISA 2018 Database, Figure V.6.2 from PISA 2018 Results - Volume V, https://doi.org/10.1787/888934131481, Table VI.4.11 from PISA 2018 Results - Volume VI, https://doi.org/10.1787/888934171191. 


\section{Socio-economic disparities in foreign-language learning time are large}

How much time students spend learning foreign languages is related to the school's socio-economic profile and the differences can be substantial. Students in advantaged schools spend more time in foreign-language classes than students in disadvantaged schools in 57 countries and economies. In Austria, Belgium, Costa Rica, Germany, Hungary, Morocco, the Netherlands and the Slovak Republic, students in advantaged schools spend at least about two additional hours on foreign-language lessons per week than students in disadvantaged schools. Only in the Dominican Republic, Israel, Macao (China), the Philippines, Portugal, Qatar, Singapore and the United Arab Emirates do disadvantaged students spend more time in foreign-language lessons at school than advantaged students.

Further research is needed to fully understand what drives the socio-economic disparities in foreign-language instruction time. Disparities may arise not just from whether different types of schools provide foreign-language lessons at all but how they do it. The choices students make about optional courses may also play a role. On average across OECD countries, students in private schools, schools located urban areas, and in upper secondary education spend more time in foreign-language lessons than those in public schools, schools in rural areas, and lower secondary education

(OECD, 2020b).

\section{The socio-economic gap in foreign-language learning time is related to inequity in student performance in core subject areas}

Inequity in learning time in foreign-language instruction is related to inequity in student achievement. Education systems with more equity in foreign-language learning time are also those with greater equity in reading performance.

This relationship was observed both across OECD countries and across all 74 PISA-participating countries and economies, even after accounting for per capita GDP. Across OECD countries, about 30\% of differences in foreign-language instruction time between students in advantaged and disadvantaged schools can be accounted for by cross-country differences in equity in reading performance. A similar pattern was also observed for equity in mathematics and science performance (OECD, 2020b).

Although no causal relationship can be established by PISA data, a possible explanation for this finding is that socio-economic inequalities in resources for students and schools influence student achievement in reading and access to foreign-language instruction at school. Shortages of teachers and staff in disadvantaged schools reduce not only the availability of foreign-language teachers but the quality of instruction in core subjects. Another possible explanation is that systems with a larger socio-economic gap in performance in core subjects prioritise disadvantaged students' learning in core subjects over foreign-language learning time. 


\section{Socio-economic disparity in foreign-language learning time and equity in reading performance}

Regular school lessons

$\begin{array}{llllll}\text { 1. Estonia } & \text { 6. Croatia } & \text { 11. Korea } & \text { 16. Italy } & \text { 21. Poland } & \text { 26. Lithuania } \\ \text { 2. Canada } & \text { 7. Jordan } & \text { 12. Indonesia } & \text { 17. Finland } & \text { 22. Saudi Arabia } & \text { 27. Chinese Taipei } \\ \text { 3. Iceland } & \text { 8. Russia } & \text { 13. United Kingdom } & \text { 18. Australia } & \text { 23. Turkey } & \text { 28. Slovenia } \\ \text { 4. Latvia } & \text { 9. Bosnia and Herzegovine Republic } \\ \text { 5. Albania } & \text { 10. Serbia } & \text { 14. Denmark } & \text { 19. Sweden } & \text { 24. United States } & \text { 29. Thailand } \\ \end{array}$

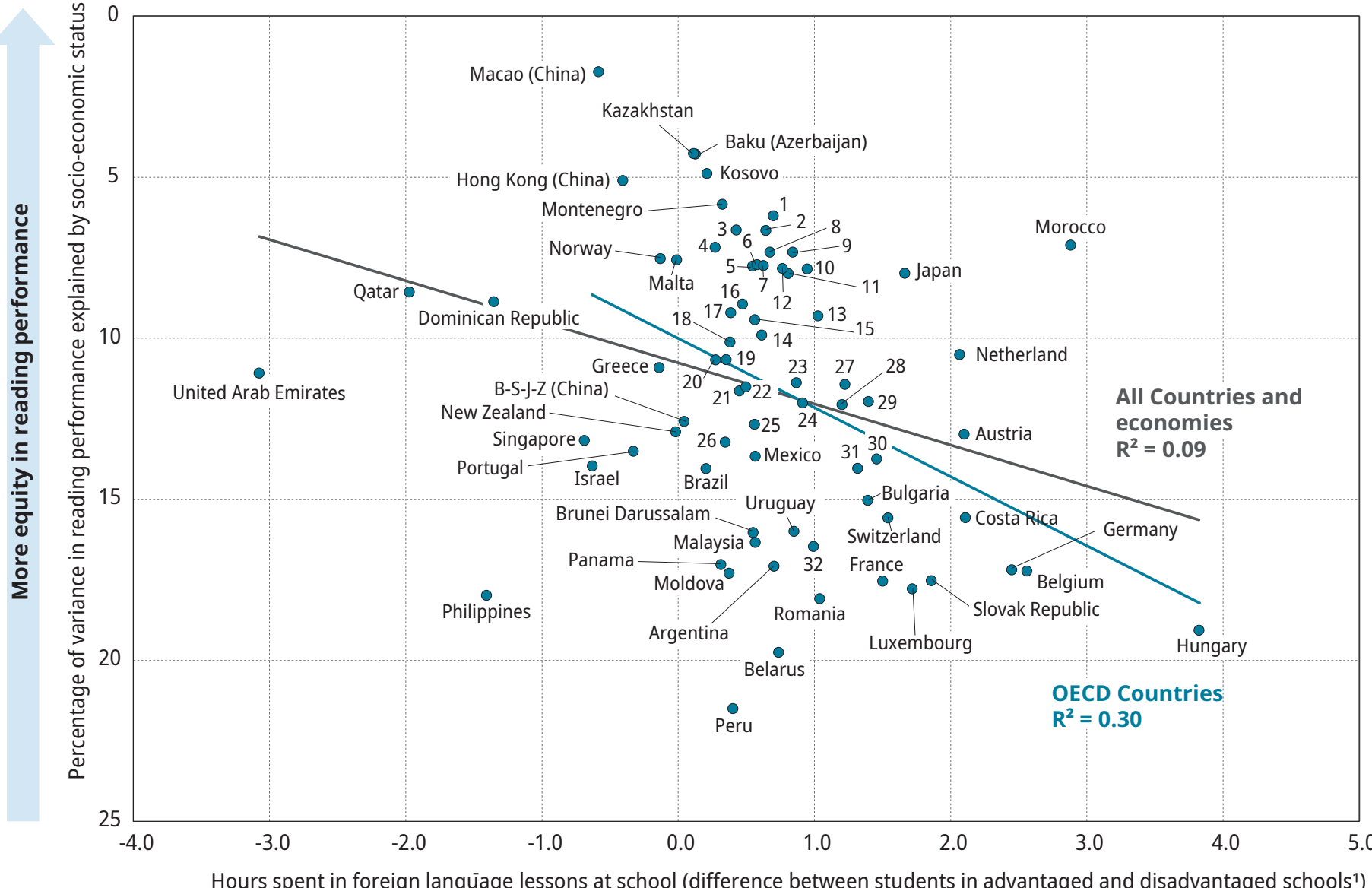

1. Socio-economically advantaged/disadvantaged schools are schools in the top/bottom $25 \%$ of the national distribution of the school-level ESCS index. The school-level ESCS index is the average ESCS index among students in a school. The ESCS index is the PISA index of students' economic, social and cultural status.

Source: OECD, PISA 2018 Database, Figure V.6.15 from PISA 2018 Results - Volume V, https://doi.org/10.1787/888934131728. 


\section{The bottom line}

Learning foreign languages is more important today than ever before. PISA data shows that opportunities for learning foreign languages are widely available to 15-year-olds in today's education systems. However, socio-economically disadvantaged students have less access than advantaged students. While further research is needed to understand the causes and consequences of socio-economic gaps in foreign-language instruction, policy makers should consider ways to address potential consequences of this socio-economic divide.

\section{Notes}

1. Foreign language refers to any language other than the language of instruction. It also includes possible other national languages of a country. In Belgium, French and Flemish are official languages and mandatory foreign languages at school, depending on the district, and German is an official language and an optional foreign language at school. In Finland, Finnish and Swedish are official languages and mandatory foreign languages at school. In Luxembourg, French and German are official languages and mandatory foreign languages at school. In Switzerland, French, German and Italian are official languages and mandatory foreign languages at school.

2. PISA measures learning time as the number of hours per week that students are required to attend regular school lessons. To create measures of learning time, PISA 2018 asked each student to report the number of class periods she or he is required to attend for specific subjects (language-of-instruction, mathematics, science and foreign language) and the average number of minutes per class period. 


\section{For more information}

Contact: Daniel Salinas (Daniel.salinas@oecd.org)

\section{References}

OECD (2020a), PISA 2018 Results (Volume VI): Are Students Ready to Thrive in an Interconnected World?, PISA, OECD Publishing, Paris, https://doi.org/10.1787/d5f68679-en.

OECD (2020b), PISA 2018 Results (Volume V): Effective Policies, Successful Schools, PISA, OECD Publishing, Paris, https://doi.org/10.1787/ca768d40-en.

This paper is published under the responsibility of the Secretary-General of the OECD. The opinions expressed and the arguments employed herein do not necessarily reflect the official views of OECD member countries.

This document, as well as any data and map included herein, are without prejudice to the status of or sovereignty over any territory, to the delimitation of international frontiers and boundaries and to the name of any territory, city or area.

The statistical data for Israel are supplied by and under the responsibility of the relevant Israeli authorities. The use of such data by the OECD is without prejudice to the status of the Golan Heights, East Jerusalem and Israeli settlements in the West Bank under the terms of international law.

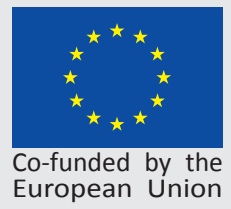

This work is available under the Creative Commons Attribution-NonCommercial-ShareAlike 3.0 IGO (CC BY-NC-SA 3.0 IGO). For specific information regarding the scope and terms of the licence as well as possible commercial use of this work or the use of PISA data please consult Terms and Conditions on www.oecd.org. 